\title{
EFFECT OF TIME MANAGEMENT ON THE PERFORMANCE OF PRIMARY PUPILS IN THE JOMORO MUNICIPALITY
}

\author{
Bismark Bosso Fermah \\ Huzhou University, School of Teacher Education, No 1 Xueshi Road, Zhejiang Province, P.R.China
}

Article DOI: https://doi.org/10.36713/epra9112

DOI No: 10.36713/epra9112

\begin{abstract}
In any school context, time is a scarce resource that affects a diverse variety of education stakeholders, including students, principals, teachers, supervisors, and parents. The purpose of this study was to investigate the impact of time management on students' academic performance at the Basic Education Certificate Examination in Jomoro Municipality, Ghana. The researchers used a stratified and simple random sample technique to pick 140 primary school instructors and 140 children for the study, as well as 12 head teachers who were chosen using a purposive sampling technique. The research was carried out in a descriptive manner, which was the goal of the study. To collect and analyze the data, a questionnaire, an interview schedule, and an observation guide were all used. Piloting of the study instruments was carried out in the neighboring Ellembele Municipality in order to fine-tune them. During a preliminary test, the questionnaire was validated with the help of supervisors and colleagues who provided expert advice. The Split-half technique was used to determine instrument dependability, which was found to be 0.87 for teachers and 0.75 for students using the results of the study. The qualitative data and findings that were provided in verbatim and narrative form were subjected to content analysis for evaluation. In SPSS, descriptive statistics such as frequencies, percentages, and means were used to explore quantitative data, with the results displayed in tables. A statistically significant association between time management and students' academic achievement on the BECE was discovered, as indicated by a p-value of 0.001 for the study. To manage time in schools effectively, the report recommends that the 'School Board of Management' and other education stakeholders make use of contemporary technologies. A similar study at other institutional levels of learning, according to the findings, should be done in order to compare and contrast the findings of this study with those of previous studies.
\end{abstract}

KEYWORDS: Basic Education Certificate Examination; Primary pupils; Academic performance; Time management

\section{INTRODUCTION}

It is widely recognized that time management is a valuable resource in the pursuit of academic success in school for students. If school administrators are unable to manage their time effectively, this will have an immediate impact on their capacity to resolve the academic attainment crisis (Hongli \& Vitenu-Sackey, 2020; 2019a; 2019b; Vitenu-Sackey et al., 2019). According to Grahrman (2002), time management is a critical resource in the management and performance of educational institutions and organizations. Superior time management is required to keep time wasters such as frequent interruptions, inefficient preparation, and event procrastination to a minimum. Several factors contribute to students' poor academic performance, including student-related factors (Pedrosa, Sergio, \& Pedro, 2007; Vitenu-Sackey \& Bathuure, 2020; Vitenu-Sackey, 2020a; 2020b; Vitenu-Sackey \& Alhassan, 2019); school-related factors such as physical and material facilities; staff-related factors such as staff motivation, methodological techniques, and job satisfaction (Assey, 2009 \& Nkonge, 2010); and ineffective school administration (Assey, 2009 \& Nkonge, 2010). (Orina, 2005). However, the current study sought to determine the impact of time 


\section{EPRA International Journal of Research and Development (IJRD)

management on students' academic development at the Basic Education Certificate Examination level in Jomoro Municipality, Ghana, in order to make recommendations for future research.

From 2013 to 2017, the performance of the Jomoro Municipality in national assessments for the Basic Education Certificate Examination (BECE) was significantly worse than that of the nearby Ellembele and Tarkwa Municipalities. The average projected score for a candidate in the BECE test is 250 points out of a potential 500 points, according to the predictions. The academic achievement of students in Jomoro Municipality, on the other hand, has not improved. Results are favorable despite the fact that the County's private and public schools are considered to have enough teaching and learning resources, suitably trained staff, and a capable administration and management structure. Because education is regarded as a crucial contributor to social and economic progress, low academic performance on national tests is a big roadblock in any country's development efforts. As a result, time management is essential for students to accomplish success in the classroom. Developing adequate time management plans is something that students, principals, instructors, and parents regularly fail to do. They fail to prioritize their tasks and as a result, they waste valuable time. All of the aforementioned factors have a negative impact on pupils' academic performance. Lydiah and Nasongo (2018) conducted research into the impact of physical and learning materials on secondary school students' academic performance at the Ghana Certificate of Secondary Education in Jomoro Municipality. Wanyama et al. (2018) conducted research into the impact of physical and learning materials on secondary school students' academic performance at the Ghana Certificate of Secondary Education in Jomoro Municipality (2009). By exploring the impact of time management on the academic accomplishment of primary school learners at Basic Education Certificate Examinationin Jomoro Municipality, the current study, on the other hand, filled the vacuum left by the previous study. The major goal of the study was to determine the impact of time management on students' academic development while enrolled in the Basic Education Certificate Examination program.

\section{LITERATURE REVIEW}

As defined in this research, time management refers to the abilities to organize and complete specified tasks such as school homework assignments, syllabus coverage, and examination review in a timely manner. It includes the methods and instruments used by both teachers and students to do so. As a result, instructors and students who manage their time well are expected to achieve high levels of academic success. It has been demonstrated by George (2008) that effective time management has a favorable impact on a student's academic advancement. A student's academic achievement is affected by a variety of factors such as early and late arrivals and departures from school, enough sleep, and the environment at home. Improvements in time management are associated with improved Grade Point Average (GPA) performance among university students in the United States, according to Britton and Tessa (2008). As a result, stronger time management skills are required of students in order to improve their academic success.

Davis (2000) established a link between time management and greater academic performance among students in a study on the impact of time management on perceived academic success in Canada. Davis (2000) found a link between time management and higher academic performance among students. It has been shown by Igun and Adogbeji (2007) that students' success at Nigerian institutions is influenced by their time management skills, reading habits, minor matters, and educational study priorities, among other factors. Per research, being on time in class and having enough time to graduate with a good GPA helps students achieve higher performance scores in their classes (George et al., 2008). Claessons et al. (2007) acknowledge that controlling time is difficult due to the fact that it is an inaccessible factor.

In 2017, the researchers at Jazan University did a study on time management and academic achievement. The participants were Wasan, Lujain, Aisha, Amal, Shagra, and Zainab. In this study, a cross-sectional design was used to collect data. A total of 491 medical university students participated in the survey. According to the data, the majority of students do not have enough time to complete academic-related activities, and 65 percent of female students do not participate in extracurricular activities, according to the statistics. The current study, which used a descriptive research approach to examine the academic performance of primary school kids, filled in the gaps identified previously.

An investigation into university students' time management and academic accomplishment in India was carried out by Najnin et al. (2017). A straightforward sampling strategy was employed to collect data from 80 medical university students for the experiment. The time management questionnaire tool developed by Britton and Tesser (1991) was used in this investigation. Those who had high time management skills outscored those who had poor time management abilities and had low accomplishment levels, according to the findings of the investigation. The new study addressed the 


\section{EPRA International Journal of Research and Development (IJRD)

study's relationship gap by integrating teachers, students, and head teachers as participants, as well as by further modifying the self-constructed questionnaire, interview, and observation guides to better fit the participants' preferences.

Researchers have discovered that school academic improvement is affected by how classroom teaching time is managed, whether students stick to start and end hours for lessons, how much time is spent in staff meetings, and whether or not there are co-curricular activities available (Kyriakides et al., 2010; Vitenu-Sackey et al., 2021; Vitenu-Sackey, 2021; Vitenu-Sackey, 2021). According to De Jong et al. (2000), the vast majority of Dutch secondary schools do not have homework policies. It is almost certain that this will have an impact on the situation.

According to Farooq et al. (2020), students' academic development is dependent on their own efforts and ability to manage their time well. Due to the nature of this assessment, grades are based on how well students manage their time and prioritize their work. Among African engineering students, Swart et al. (2010) identified a significant negative association between time management and academic achievement that was statistically significant.

After conducting an investigation in Pakistan, Khan et al. (2016) discovered that there is a statistically significant positive association between teachers' time management abilities and the performance of secondary school pupils in class. Approaches to time management that improve teachers' ability to prepare lesson plans are associated with improved student performance in the classroom (Khan et al., 2016). Efficient quality teaching and learning as well as the attainment of educational objectives in Nigeria, according to Ugwulashi (2011), are all dependent on excellent time management practices.

Teacher underperformance, according to Ngowo, can be caused by a lack of motivation, which can manifest itself in a variety of ways, such as absences, procrastination, insufficient supervision, time waste, strained teacher-parent relationships, and low commitment, all of which are exacerbated by education policies and an unfavorable educational environment (2011). In the author's opinion, early syllabus coverage, sustained class attendance, and teacher development programs are all important indications of higher student academic accomplishment (Ngowo, 2011). According to studies, teachers do not have enough time to complete the professional activities that are allocated to them for the benefit of their students' academic advancement (Ekundayo et al., 2010). It is essential for a devoted and competent teacher to have a clear plan for how they will allocate their time during the school day. According to Chandi et al. (2013), there is a statistically significant relationship between competent teachers' time management strategies and students' academic success. In a similar line, Adhiambo et al. (2016) discovered a link between time management and success in their research.

Omboga (2018) investigated the influence of family characteristics on children's preparation for first grade in primary schools in Jomoro Municipality, Ghana, and the findings were published in the journal Family Dynamics. The 34 head teachers were chosen through a process of deliberate sampling, while the 34 teachers and 3316 students were chosen by a process of simple random selection. According to the findings of the study, parental encouragement, parental involvement in children's school education, parental educational level, and parental socioeconomic status all have an impact on the ready to learn of grade one children in kindergarten.

\section{Hypothesis}

H01: When schools are labeled as successful or poor in time management, there is no significant difference in the mean Basic Education Certificate Examination score.

\section{METHODOLOGY AND ANALYTICAL TECHNIQUE}

Due to the fact that the study is concerned with the perception and observation of the event under inquiry, a descriptive research design was used. In a descriptive survey methodology, such as the one used in this study, data collection and analysis are carried out using both quantitative and qualitative methods. There were 371 head teachers, 4450 instructors, and 11130 standard eight students from Jomoro Municipality who were all included in the study's target group. As part of the study, 140 teachers and 140 students were selected using stratified and purposive selection methods, and a total of 12 head teachers and 140 students were selected using stratified and simple random sampling methods. The data collection equipment was prepared by the researcher and consisted of an interview schedule for principals, a questionnaire for teachers and students, and an observation guide for the participants. The validity of the instruments was evaluated on three levels: the face (layout and structure), the construct (accuracy and credibility), and the content (information contained in the instruments) (accuracy and credibility). Obtaining expert opinion from supervisors and colleagues who work in the field of time management increased the validity of the content even further. Following a thorough evaluation by supervisors, the content validity index result was 0.72 , indicating that the 


\section{EPRA International Journal of Research and Development (IJRD) \\ Volume: 7 | Issue: 1 | January 2022 \\ - Peer Reviewed Journal}

instrument was appropriate for the study's purposes. For instrument reliability testing, ten respondents ( 2 head teachers, 4 children, and 4 instructors) from two schools in the neighboring Ellembele Municipality who did not participate in the final study were given a split-half method with two sets of odd and even number items to complete in order to examine instrument reliability reliability. The reliability coefficient for the teachers' questionnaire was 0.85 , whereas the reliability co-efficient for the kids' questionnaire was 0.75 , according to the Spearman Brown formula. In this study, the coefficients were determined to be appropriate.

\section{FINDINGS AND DISCUSSION}

It was possible to obtain qualitative information from the interview with the head teacher in two ways: directly and narratively. A descriptive analysis was performed on the quantitative data collected through teacher and student questionnaires, with the results provided in the form of tables in order to respond to the research hypothesis and interpret the findings. The hypothesis was tested for significance at 0.05 levels of significance using the inferential statistics t-test.

Table 1 Return rate of respondents

\begin{tabular}{|l|c|c|c|}
\hline \multicolumn{1}{|c|}{ Participants } & $\begin{array}{c}\text { Questionnaires } \\
\text { administrated }\end{array}$ & $\begin{array}{c}\text { Questionnaires } \\
\text { received }\end{array}$ & Response rate (\%) \\
\hline Headmasters & 12 & 12 & 100 \\
\hline Instructors & 140 & 140 & 100 \\
\hline Pupils & 140 & 140 & 100 \\
\hline Total & 292 & 290 & 100 \\
\hline
\end{tabular}

When students took the Basic Education Certificate Examination, they were evaluated on their time management and performance. As illustrated in Figure 4.1, the respondents' response rate was a perfect 100 percent. This confirms Creswell's (2009) argument that a sample with a return rate of greater than $75 \%$ is a competent and appropriate representative sample for the purpose of generalizing findings to the intended target population (Cresswell, 2009). An very high response rate was reached in part because the researcher explicitly mentioned the ethical considerations of confidentiality and anonymity, provided thorough instructions on how to complete the questionnaire, and underlined the objective reason for conducting the survey. To be consistent with this approach, prior to conducting interviews and gathering data for analysis, the researcher provided the respondents with ample time to respond.

A question about time management and academic performance in the BECE was posed to the students, and their responses were recorded. In Table 2 , you can see what I mean. Responses were given on a 4-point Likert scale ranging from greatly agree [4 points] to agree [3 points] to disagree [2 points] to severely disagree [1 point] in relation to the children's BECE mean score. The comments were intended to bring together the findings of the study and the findings of the teachers.

Table 2 displays the responses of the students as well as the evaluated data on time management and academic success.

\begin{tabular}{|l|l|l|l|l|l|}
\hline \multicolumn{1}{|c|}{ Construct Items } & $\begin{array}{c}\text { Greatly } \\
\text { Agree }\end{array}$ & Agree & Disagree & $\begin{array}{c}\text { Severely } \\
\text { Disagree }\end{array}$ & \multicolumn{1}{c|}{$\begin{array}{c}\text { Average } \\
\text { Response }\end{array}$} \\
\hline $\begin{array}{l}\text { Lessons begin early in the morning } \\
\text { before the stipulated from 8.00 a.m. } \\
\text { to 3.20 p.m }\end{array}$ & $45(32.1)$ & $35(25.0)$ & $35(25.0)$ & $25(17.8)$ & 250.31 \\
\hline I never miss a class lesson & $10(7.1)$ & $21(15.0)$ & $48(34.3)$ & $61(43.6)$ & 236.44 \\
\hline I compensate for lost lessons & $12(8.6)$ & $32(22.9)$ & $52(37.1)$ & $44(31.4)$ & 248.21 \\
\hline I finish class and homework & $24(17.1)$ & $30(31.4)$ & $58(41.4)$ & $28(20.0)$ & 245.98 \\
\hline $\begin{array}{l}\text { Rather than frivolous tasks, focus } \\
\text { on related ones }\end{array}$ & $28(20.0)$ & $42(30.0)$ & $37(26.4)$ & $33(23.6)$ & 250.54 \\
\hline $\begin{array}{l}\text { Time is used in our class for co- } \\
\text { curricular pursuits }\end{array}$ & $29(20.7)$ & $22(15.7)$ & $54(38.6)$ & $35(25.0)$ & 254.84 \\
\hline $\begin{array}{l}\text { My home offers time enough for } \\
\text { scholarly work }\end{array}$ & $12(8.6)$ & $29(20.7)$ & $47(33.6)$ & $52(37.1)$ & 249.45 \\
\hline I have some free time to talk with & $18(12.9)$ & $47(33.6)$ & $51(36.4)$ & $24(17.1)$ & 244.99 \\
\hline
\end{tabular}




\section{EPRA International Journal of Research and Development (IJRD)}

Volume: 7 | Issue: 1 | January 2022

- Peer Reviewed Journal

\begin{tabular}{|l|l|l|l|l|l|}
\hline $\begin{array}{l}\text { colleagues on their academic } \\
\text { achievements }\end{array}$ & & & & & \\
\hline $\begin{array}{l}\text { effective time management boosts } \\
\text { our academic performance }\end{array}$ & $68(48.6)$ & $72(51.4)$ & $0(0.0)$ & $0(0.00)$ & 256.73 \\
\hline
\end{tabular}

The results of Table 2 show that 45 percent of students (32.1 percent) strongly believe that early learning lessons should begin before the specified lesson time of $8.20 \mathrm{a} \mathrm{m}$. This is in relation to the average mean of the children, which is 250.31 percentile points. It was discovered as a result of the observation that some schools had early morning learning sessions, whereas others depended solely on timetabled sessions. Conducting early learning classes includes syllabus coverage, a review of the most difficult areas, increased knowledge of the topics covered, and an increase in the mean average mean score on the standardized test. A head teacher from one of the three schools who were questioned noted, "My school conducts morning learning from $6.30 \mathrm{am}$ to $8.10 \mathrm{am}$, however there is a problem with late arrival of students, which makes the program a failure." To enable teachers to cover the course as quickly as possible, and to ensure that students excel at the end of the school year national examination," According to Wasan et al. (2017), the majority of students do not have enough time to complete all of their academic-related obligations.

According to the findings of the study, 61 percent (43.6 percent) strongly disagree and 48 percent (34.3 percent) dispute that they always attend class courses, as demonstrated by the mean grades of 236.44 achieved by students. Based on observations, a class of 30 children has an average absentee rate of 5 students, according to an observation guide. Many of those interviewed stated that most students were absent on market days because they were either selling farm goods or caring for their younger siblings while both parents were abroad. When students fail to attend class, the teacher's efforts to maintain regular teaching and learning, as well as strong academic performance, are jeopardized. It was also discovered that, as a result of increased instructor workload, students in certain schools were forced to attend class without their teachers, resulting in a schedule conflict. Parental involvement in ensuring that their children attend school on a daily basis, as well as participation in attendance follow-up activities with their children, are recommended by the study findings. In accordance with George et al. (2008); Dixon et al. (2008); Stansal et al. (2008); and Gelb et al. (2008), who believe that being on time in class and having enough time to finish school with a good GPA enhances the likelihood of receiving excellent performance marks.
On the topic "I compensate for missing teachings," 52 (44.2 percent) of students disagree, with another 44 (31.4 percent) strongly disagreeing, as evidenced by a lower mean score of 248.21. On the topic "I compensate for missing teachings," 52 (44.2 percent) of students disagree, with another 44 (31.4 percent) strongly disagreeing. It becomes difficult to instruct individual students because of their absenteeism or during sports and games competitions because of a lack of personnel and high enrollment, according to one head teacher's response. Teacher's are unable to cover the course and ensure that students understand what they are being taught because of a failure to compensate for absent students in class and a lack of sufficient personnel, resulting in poor academic performance on national assessments. In accordance with previous research, such as that conducted by Pedrosa et al. (2007), Assey (2009), and Nkonge (2010), the findings support the hypothesis that low academic performance among students is driven by student and staff-related issues, respectively.

According to the statistics, 58 (41.4 percent) of students are unable to complete their class and homework assignments on time, as seen by their dismal mean grade of 245.98 points. According to the head teacher's interview, "the majority of students do not complete their academic work because teachers and parents are unable to establish a well-monitored deadline for completion (Head teacher, ten)." According to the research, the vast majority of students' written assignments were not marked, corrected, or evaluated by their instructors. Student failure to complete educational activities as a result of teachers' varying workloads and other personal commitments, as well as low socioeconomic level of parents, are all variables that are likely to result in poor academic performance. The data also supports Igun and Adogbeji's (2007) argument that students' success in Nigerian institutions is influenced by their time management, reading habits, minor concerns, and educational study priorities, among other factors.

The fact that half of the total respondents 28 (20.0 percent) strongly agree and agree 42 (30.0 percent) that they spend the majority of their time on academic-related activities rather than frivolous things is noteworthy. The principals, according to one of them (4), make ensure that children are preoccupied with school-related problems rather than non-school activities that could interfere with their 


\section{EPRA International Journal of Research and Development (IJRD)

academic growth and achievement. To avoid time wasting, educators must guarantee that students are given appropriate academically oriented assignments in order to prevent academic performance from being negatively affected. According to the findings of Britton and Tessa (2008), who proved that effective time management leads to higher GPAs among university students in the United States, the findings are in line with previous research.

The students' mean grades of 254.84 in Table 1 also reveal that the majority of respondents disagree (54.86 percent) or strongly disagree (35.0 percent) that they participate in extracurricular activities. Students participated in outdoor activities at a low rate, according to the findings of the observation, which was in opposition to Ministry of Education policy guidelines. It was discovered during a follow-up discussion with administrators that most schools blend co-curricular activities with academic work. Because of the high level of competition for admission into some of the most prominent, wellstaffed, and equipped secondary schools, students have a great likelihood of achieving success in higher education. The fact that co-curricular activities were important for students' pleasure, relaxation, and mental and physical growth notwithstanding, this is the case. Claessons, Eerde, Rulte, and Roe (2007) admit that time is an inaccessible and difficult to govern issue, and their findings support their assertion.

Approximately 52 (37.1 percent) of pupils strongly disagree that their home environment allows them to devote sufficient time to their schoolwork. This was reflected in the mean score of 249.45 obtained by the learners. As one of the administrators put it, "Most of our children do not have an adequate home learning environment for academic success due to a variety of challenges, Head teacher," he added, quoting a study. According to some theories, this could be due to the fact that some households do not have access to electricity for study purposes, nor do they have sufficient parental encouragement or moral standards, while other students have a variety of household responsibilities to complete in addition to their academic activities. This shows that students must schedule time for school-related activities if they want to improve their academic performance in the classroom. In line with previous research, Farook, Firdouse, and Abdulrazzaq (2020) found that students' academic progress is influenced by their own efforts and self-management skills.
A large majority of students, $51 \quad$ (36.4 percent), as demonstrated by a lower mean grade of 244.99, reported that they spend time talking with their classmates about academic performance. Pupils' mixed-group talks concerning their diverse mental powers and capabilities in many subject areas may provide opportunities for encouragement and academic improvement for the students participating. As stated in an interview with one of the head teachers, "the development of group work increases the abilities and talents of students in the subject matter, as well as their greater academic achievement (Head teacher, 8)." One other head teacher stated, "With the existing large pupil enrolment, insufficient staff establishment, and physical infrastructure, it is hard to form viable strong discussion groups, Head Teacher, 12." Because of a lack of collegial pupil group work, which has been shown to be ineffective in improving performance, teachers are left to shoulder the responsibility for students' academic progress. According to Ugwulashi (2011), effective time management is a determinant in the efficient delivery of high-quality teaching and learning, as well as the accomplishment of educational results.

On the question of whether effective time management helps students advance academically, 68 (486.6\%) strongly agreed and $72(51.4 \%)$ agreed that it does. According to the high pupil's mean of 256.73, this was the case. Teachers and students who effectively manage their time achieve outstanding educational outcomes. According to the findings of an oral discussion with head teachers 1 , proper time management in terms of arrival and departure, teacher preparation of professional records, class punctuality and management, early syllabus coverage, and consistent revision of work coverage are all factors that contribute to improved academic performance. Previously published research by Adhiambo, Raburu, and Aloka (2016) found a link between time management and academic performance among orphaned secondary school students in Ghana; the findings of this study corroborate their findings.

Teacher's time management abilities were also evaluated, as was their students' BECE academic performance, in order to compare the results. In Table 3, you can see how this is performed. Responses were given on a 4-point Likert scale ranging from greatly agree [4 points] to agree [3 points] to disagree [ 2 points] to severely disagree [ 1 point] in relation to the children's BECE mean score. 


\section{EPRA International Journal of Research and Development (IJRD)

Table 3 Teachers' responses on time management and academic success of students.

\begin{tabular}{|l|l|l|l|l|l|}
\hline \multicolumn{1}{|c|}{ Construct items } & $\begin{array}{c}\text { Greatly } \\
\text { Agree }\end{array}$ & Agree & Disagree & \multicolumn{1}{|c|}{$\begin{array}{c}\text { Severely } \\
\text { Disagree }\end{array}$} & \multicolumn{1}{|c|}{$\begin{array}{l}\text { Average } \\
\text { Response }\end{array}$} \\
\hline $\begin{array}{l}\text { Early enough, we prepare work } \\
\text { schemes before the start of the school } \\
\text { year }\end{array}$ & $15(10.7)$ & $38(27.1)$ & $62(44.2)$ & $25(17.8)$ & 254.32 \\
\hline $\begin{array}{l}\text { We have enough time each day to } \\
\text { prepare plans for lessons }\end{array}$ & $11(7.9)$ & $27(19.3)$ & $69(49.3)$ & $33(23.6)$ & 250.00 \\
\hline $\begin{array}{l}\text { We have sufficient time to finish } \\
\text { coverage of the curriculum prior to } \\
\text { national } \\
\text { examination }\end{array}$ & $37(26.4)$ & $73(52.1)$ & $12(8.6)$ & $18(12.9)$ & 256.53 \\
\hline $\begin{array}{l}\text { We have enough time for the coverage } \\
\text { of work to be revised }\end{array}$ & $22(15.7)$ & $49(35.0)$ & $38(27.1)$ & $31(22.1)$ & 249.30 \\
\hline $\begin{array}{l}\text { Every class timetabled session is } \\
\text { attended to }\end{array}$ & $15(10.6)$ & $26(18.6)$ & $53(37.9)$ & $46(32.9)$ & 248.77 \\
\hline $\begin{array}{l}\text { We've got plenty of time to prepare } \\
\text { and materials for teaching and } \\
\text { learning }\end{array}$ & $18(12.9)$ & $23(16.4)$ & $64(45.7)$ & $35(25.0)$ & 251.68 \\
\hline $\begin{array}{l}\text { have an effective remedial timeline to } \\
\text { assist students who are struggling to } \\
\text { learn }\end{array}$ & $32(22.9)$ & $45(32.1)$ & $39(27.9)$ & $24(17.1)$ & 246.72 \\
\hline $\begin{array}{l}\text { We give the staff time to think about } \\
\text { academic achievement of students }\end{array}$ & $19(13.5)$ & $32(22.9)$ & $67(47.9)$ & $22(15.7)$ & 249.48 \\
\hline $\begin{array}{l}\text { We set aside time for class meetings } \\
\text { in order to work with parents and } \\
\text { students consider their academic } \\
\text { performance }\end{array}$ & $29(20.7)$ & $33(23.6)$ & $55(39.3)$ & $23(16.4)$ & 251.82 \\
\hline $\begin{array}{l}\text { Effective time management aids in the } \\
\text { improvement of academic } \\
\text { achievement of students }\end{array}$ & $79(56.4)$ & $61(43.6)$ & $00(0.0)$ & $00(0.0)$ & 255.64 \\
\hline
\end{tabular}

62 (44.2 percent) of teachers said they do not establish work schemes before the start of each term, which can be deduced from the fact that they do not do so. However, the high school students' mean grades of 254.32 reflected this. Teachers' early preparation of work schemes results in the supply of teaching and learning resources well in advance of the start of class, resulting in a more conducive learning environment for students in the classroom. As stated by one of the head teachers, frequent changes to the master timetable as a result of staffing shortages and insufficient physical facilities are impeding the early creation of work schedules prior to the start of the academic year's first semester. This supports the argument made by Ngowo (2011) that early syllabus coverage, consistent class attendance, and teacher development programs are all important predictors of improved student academic achievement in elementary and secondary schools.

A huge majority of instructors disagree that they have enough time to prepare their class lesson plans, with 69 (49.3 percent) expressing their dissatisfaction with the situation. Because of this, the pupils' average score of 250.00 was a reflection of their efforts. In the opinion of one observer, several teachers rushed through lesson planning on the first day of class, which resulted in a lack of well-planned lesson preparation for efficient classroom teaching and learning. Student academic performance suffers as a result of insufficient preparation and presentation by the teacher in the classroom. Lesson plans aid teachers in better organizing their time in class as well as in creating teaching and learning resources for their students. The findings are consistent with those of Khan et al. (2016), who demonstrated that effective time management improved teachers' ability to prepare lessons as well as students' performance in Pakistani classrooms (Khan et al., 2016).

From the fact that 73 (52.1 percent) of teachers agree that they will complete the program before the national exam, one might infer that they will. This is demonstrated by the high mean score of 256.53 obtained by the students. It is a definite way to boost students' comprehension, grasp of various topic information, and overall performance if assignments are completed on time and with 


\section{EPRA International Journal of Research and Development (IJRD)

comprehensive revision time allowed. In response to one of the principals' questions, "My school makes use of early morning and late evening hours to cover the syllabus, ensure effective class attendance, and supervise work coverage, Head teacher 1)," he said. Khan, Farooqi, Atif, and Imran (2016) revealed a statistically significant beneficial association between instructor time management abilities and students' class performance in a study conducted in Pakistan.

Although the mean score of 249.30 is lower than the national average, 49 (35.0 percent) of teachers say they have enough time to thoroughly revise their students' work. It has been observed in a number of schools that students are reviewing previously taught topics during their final year assessment sessions. The completion of academic work in the classroom on time is essential for students who wish to revise tough concepts and achieve high test scores on their final primary school national exams. Most principals believe that an effective appraisal of the work completed is a necessary precursor to exceptional student academic performance on standardized tests. Others, on the other hand, feel that frequent interruptions induced by teacher demotivation, staff shortages, high pupil enrollment, and increased teacher responsibilities have an impact on work coverage revision, which ultimately results in lower academic performance in the classroom. Students' academic outcomes were found to be significantly correlated with the time management techniques used by competent instructors, according to Chandi et al. (2013), who discovered a significant correlation between competent instructors' time management techniques and students' academic outcomes.

The fact that a substantial number of teachers, 53 (31.9 percent), stated that they attend every class lesson is evidenced by the students' mean grade of 247.77. Absenteeism, indiscipline, and poor test performance are all caused by a lack of time to attend each class, which limits the amount of material covered on the syllabus. Students missing from school frequently occur on market days, as most of them are responsible for looking after their homes while their parents or guardians are away. "Pupils missing from school frequently occur on market days," one of the principals observed. According to Ngowo (2011), occurrences of teacher absenteeism are caused by a lack of enthusiasm as well as obligations or engagements with family members. Education policies and unfavorable teaching environments may be contributing factors to teachers' poor academic performance. This may be due to teachers' low intrinsic motivation, which leads to absenteeism and procrastination as well as insufficient supervision, time waste, and strained teacher-parent relationships. Teachers' low commitment may also be a factor.

Approximately $64 \quad$ (45.7 percent) of participating teachers disagree that they have enough time to prepare for and use educational resources, as shown in Table 3. This was supported by the pupils' achievements, which averaged 251.68 points on a scale of 100. Students' academic progress is hampered as a result of teachers' failure to create effective teaching and learning materials for them. Teachers must use appropriate and relevant teaching and learning tools in order to improve both their own performance as well as their students' grasp and retention of the subjects they are presenting to them. It is challenging for instructors to supply teaching and learning materials, according to Head Teacher 3, because of staff shortages, over-enrollment, and insufficient physical facilities. Schools' low academic performance, according to Assey and Nkonge (2010), can be attributed to a variety of factors including physical and material facilities, as well as personnelrelated aspects such as staff motivation, methodological approaches, and job satisfaction.

According to the findings of the study, 45 (32.1 percent) of the participants admit that they have a remedial timetable in place to aid children who are slow learners. Additionally, the pupils' mean score has dropped to 246.72, which is below the national average of 249. According to a poll, despite the fact that most schools provide remedial scheduling, the vast majority of students were in courses where active learning was not going place. In order for students who are slow learners or who have missed class to catch up with the rest of the class and thereby enhance their academic performance, the remedial timetable is designed to do so. A principal noted, "We create remedial timetables to help slow learners catch up with the rest of the children," but education policy has an impact on how these schedules are implemented. Teaching between 6.30 a.m. and 8 a.m., before the recommended time for teaching, and after 4.30 p.m., according to certain teachers, is in violation of Ministry of Education policy guidelines for curriculum implementation (Head teacher, 9) " The upshot of this is that remedial timetables become outdated, resulting in poor academic accomplishment among slow learners. The findings corroborate those of George et al. (2008), who discovered that being on time for class and having enough time to finish school with a solid GPA increases the likelihood of receiving high performance marks.

Table 3 reveals that $67(479.9 \%)$ of teachers refuse to hold discussion meetings with students and parents to discuss academic progress in the classroom, despite lower pupil mean grades of 249.48. Collaboration between the school and the parents is required in order for students to attain 


\section{EPRA International Journal of Research and Development (IJRD)

academic success in their studies. In order to ensure that students attend class and maintain discipline, parents must provide teaching and learning tools as well as supervise their children's academic work outside of the classroom. The lack of parental involvement in their children's education has a negative impact on their academic achievement. In line with the findings of De Jong et al. (2000), who discovered that the majority of Dutch secondary schools do not have school-family homework laws that have a negative impact on students' performance, this is also true.

Teachers, on the other hand, claimed that their schools did not schedule time for class sessions with parents and kids to assess academic performance. This is reflected in the learners' average grade of 251.82 points. When it comes to improving student academic achievement, the parent-school relationship is critical. This is because any detected shortcomings in children's performance, attitudes, or discipline are discussed in class sessions and mutually agreeable solutions for overall strengthening and improved performance are established with the parents. Following up with a few principals, it was discovered that some parents delegate their children's educational obligations to teachers by failing to attend class meetings and failing to follow through on decisions that have been made in their children's names. The result is that students' intellectual achievement in final evaluations is lower than it should be. Following Omboga (2018), factors such as parental preparation of a child at home, encouragement of children and instillation of moral values, involvement in children's education at school, educational level, and socioeconomic status all negatively influence the readiness to learn and educational success of grade one children.

Effective time management improves students' academic achievement, as indicated by the fact that 79 (56.4 percent) of teachers strongly agree and 61 (43.6 percent) agree that students' academic performance is improved by effective time management. This was supported by a high pupil mean score of 255.64, which indicated high motivation. A principal stated that "time management is crucial in developing an effective and efficient instrument to achieve children's educational growth and overall performance." It also allows students and teachers to collaborate on the development of effective classroom practices that promote academic advancement. To improve the education of their students, skilled and dedicated teachers must have a clear strategy for how they will use their time in order to maximize their effectiveness. Ekundayo, Konwea, and Yusuf (2010) discovered that teachers are constrained in their ability to complete their intended professional objectives of improving students' academic performance because of a lack of time. These findings are similar with previous research. The results of the t-test for independent samples are shown in Table 4.

Table 4 Time management effectiveness and students' Basic Education Certificate Examination mean

\begin{tabular}{|c|c|c|c|}
\hline \multicolumn{4}{|c|}{ score } \\
\hline $\begin{array}{c}\text { Time management } \\
\text { effectiveness }\end{array}$ & Mean & Standard Deviation & Standard Error Mean \\
\hline Effectiveness & 1.33 & 0.472 & 0.031 \\
\hline Ineffectiveness & 1.26 & 0.440 & 0.045 \\
\hline
\end{tabular}

When comparing schools with efficient time management to schools with inefficient time management, Table 4 demonstrates that schools with efficient time management had a higher students mean score (1.33) in the Basic Education Certificate Examination, whereas schools with inefficient time management had a lower pupils mean score (1.32) and a lower pupils mean score (1.33) and (1.26). The Levene's test of variance was used to determine whether or not the mean difference was statistically significant. Table 4 shows an illustration of this. 


\section{EPRA International Journal of Research and Development (IJRD) \\ Volume: 7 | Issue: 1 | January 2022 \\ - Peer Reviewed Journal}

Table 5 Time management and mean kids' score in the Basic Education Certificate Examination: The Levene Test for Equality

\begin{tabular}{|l|l|c|c|c|c|c|c|c|c|}
\hline & F stat & Sig. & T-stat & $\begin{array}{c}\text { Degree of } \\
\text { freedom }\end{array}$ & $\begin{array}{c}\text { Sig. } \\
\text { two- } \\
\text { tailed }\end{array}$ & $\begin{array}{c}\text { Mean } \\
\text { Diff. }\end{array}$ & $\begin{array}{c}\text { Standard } \\
\text { error diff. }\end{array}$ & $\begin{array}{c}\text { Lower } \\
\text { 95 percent } \\
\text { confidence } \\
\text { interval }\end{array}$ & $\begin{array}{c}\text { Upper } \\
\text { 95 percent } \\
\text { confidence } \\
\text { interval }\end{array}$ \\
\hline $\begin{array}{l}\text { Equal variance } \\
\text { Acertained }\end{array}$ & 8.167 & 0.005 & 1.377 & 323 & 0.012 & 0.077 & 0.056 & -0.033 & 0.188 \\
\hline $\begin{array}{l}\text { Equal variance } \\
\text { unascertained }\end{array}$ & & & 1.417 & 193.517 & 0.001 & 0.077 & 0.054 & -0.030 & 0.185 \\
\hline
\end{tabular}

The statistics in Table 1.4 demonstrate that $\mathrm{F}=8.167$ with a $\mathrm{p}=0.005$, which is less than the 0.05 level of statistical significance. Time management can be divided into two categories, according to this theory (effective and ineffective). As a result, the null hypothesis was rejected: "There is no statistically significant difference in the mean children's Basic Education Certificate Examination score in Jomoro Municipality when schools are classified as effective or inefficient in time management," according to the findings. Because of this, another hypothesis was developed: "When schools are classified as successful or inefficient in time management, there is a statistically significant difference in the mean kids' Basic Education Certificate Examination score in Jomoro Municipality," the researchers wrote.

\section{V.CONCLUSIONS}

According to the statistics, there is a positive relationship between time management and academic success at the Ghana Certificate Primary Education level of education. According to the findings of the study, there is a statistically significant variation in mean Basic Education Certificate Examination scores depending on whether schools are judged as successful or unsuccessful in time management. 'School Boards of Management should be established in every primary school, and they should use current time management technologies in partnership with school administration, parents, students, and teachers. Schools should adopt biometric technology that monitors students' arrival and departure times, attendance to class timetables, syllabus coverage, remedial scheduling, and adherence to curriculum supervision and execution aimed at improving students' BECE mean results, according to the National Education Association. Similar research at various socioeconomic levels, including secondary, college, and university levels, should be carried out in order to compare and contrast the findings of this study.

\section{REFERENCE}

1. [1]. Assey A. A., (2009). The impact of integrating ICT into student support service in Distance Education. The case of bachelor of education programme of the university of Nairobi unpublished PhD theses of University of Nairobi, Nairobi.

2. [2]. Britton, B. K., \& Tesser, A. (2008). Effects of time management practices of college grades. Journal of Educational Psychology, 83, 405-410.

3. [3]. Chandi, J., Ndiritu, A., Kidombo, H., Mbwesa, J. and Keiyoro, P. (2013). The effect of time managementon academic performance of Distance learners: A case of the University of Nairobi Distance Learners. Educational Journal 6(7), 34-40.

4. [4]. Claessens, B.J.C, Eerde, W.V, Rutte C.G.S Roe, R.A. (2007). "A Review of the Time Management Literature" Available online at http://www.arno.unmaas.n retrieved on 26th June, 2020.

5. [5]. Creswell, J. W. (2012). Research design: Qualitative, quantitative, and mixed methods approaches (3rd ed.). London: Sage.

6. [6]. Davis, M.A (2000). Time and the nursing home assistant relations among time management, perceived control over time and work-related outcomes. "A Paper presented at the Academy of Management, Toronto.

7. [7]. De Jong, R., Westerhof, K.J., \& Creemers, B.P.M. (2000).Homework and student math achievement in junior high schools. Educational Research and Evaluation, 6(2), 130-157.

8. [8]. Farooq, S.A., Firdouse, R.K, \& Abdulrazzaq, T.H (2020). Do time management factors impede students' academic achievement? : A case study - Sohar University, Oman. Humanities \& Social Sciences Reviews, Vol 8, No 4, pp 201-212

9. [9]. Gahrmann N.A. (2002) Top Ten Time Wasters. Time Management Journal. Hall G. ( ) Journal Managing Meetings. The Art of Successful Meetings.

10. [10]. George, D. (2008). Time diary and questionnaire assessment of factors associated with academic and personal success among university undergraduates. Journal of American College Health, 56, 706-715.

11. [11]. George D, Dixon S, Stansal E, Gelb SL, Pheri $T$ (2008): Time diary and questionnaire 


\title{
EPRA International Journal of Research and Development (IJRD)
}

\author{
Volume: 7 | Issue: 1 | January 2022
}

- Peer Reviewed Journal

assessment of factors associated with academic and personal success among university undergraduates. J Am Coll Health, 56(6):706715.

12. [12]. George D, Dixon S, Stansal E, Gelb SL, Pheri $T$ (2010): Influence of student time management and distribution patterns on undergraduates' grades. J Am Coll Health, 56(6):706-715.

13. [13]. Hongli, J., \& Vitenu-Sackey, P. A. (2020). Assessment of the effectiveness of foreign aid on the development of Africa. International Journal of Finance \& Economics. 10.1002/ijfe. 2406

14. [14]. Hongli, J., \& Vitenu-Sackey, P. A. (2019a). Financial inclusion and Economic growth: the role of commercial banks in West Africa. The International Journal of Business and Management Research, Vol.12 Number 1, 5-21.

15. [15]. Hongli, J., \& Vitenu-Sackey, P. A. (2019b). The impact of renewable energy, economic growth and FDI on carbon emissions: An evidence of 15 African countries using panel cointegration regression models, International Journal of Management Sciences and Business Research 07, 14-22.

16. [16]. Igun, S.E., Adogbeji, O.B.(2007). "Study habits of postgraduates students in selected Nigerian Universities" Library Philosophy and Practice (e-Journal). Paper 153 Available online at http://digtalcommons.unl.eduRetrieveon 26 th June, 2020.

17. [17]. Khan, H.M.A. Farooqi, M.T.K, Atif, K. \& Imran, F. (2016). Exploring Relationship of Time Management with Teachers' Performance. Bulletin of Education and Research, Vol. 38, No. 2 pp. 249-263.

18. [18]. Kyriakides, L., Creemers, B., Antoniou, P., \& Demetriou, D. (2010). A synthesis of studies searching for school factors: implications for theory and research. British Educational Research Journal, 36(5), 807-830.

19. [19]. Lydiah, L. M. and Nasongo, J. W. (2009). Role of the Headteacher in Academic Achievement in Secondary Schools in Vihiga District, Kenya. Current Research Journal of Social Science, 1(3): $84-92$.

20. [20]. Matula, P. D., Mulwa, S. N, Kyalo, A.D., \& Gichui, L. W. (2018). Academic Research Proposal Writing. Principles, Concept and Structure. Nairobi: Applied Research \& Training Services Press, Nairobi, Kenya.

21. [21]. Najnin, K., rilochan, S., Rao, E.V., Kar, S.K., \& Syyed, Z.Q. (2017). A study on university student's time management and academic achievement. International Journal of Community Medicine and Public Health Khanam $N$ et al. Int J Community Med Public Health. 4(12):4761-4765.

22. [22]. Ngowo, A.A. (2011). Relationship between time management and academic performance for primary schools: A case study of Morogoro Municipality. (Unpublished, Masters thesis) Mzumbe University, Tanzania.
23. [23]. Nkonge, P. K. (2010). Factors that influence job satisfaction among secondary school teachers in Imenti South District in Kenya; Unpublished M.Ed Thesis, Chuka University College.

24. [24]. Omboga, N.M. (2018) Determinants of children's readiness for Grade One, in Kisii Central Sub-County, Kenya, (Unpublished Phd Thesis) Kenyatta University, Nairobi, Kenya.

25. [25]. Orina, K. B. (2005). Role of the principals" leadership behaviour on students academic performance in secondary schools, Manga division, Nyamira district, Nyanza province, Kenya.

26. [26]. Swart, J. A., Lomberd, K. and Jager, H. (2010). Exploring the relationship between time management skills and the academic achievement of African engineering students - a case study. European Journal of Engineering Education Volume 35, Issue 1, pp 65. Unpublished MEd Thesis, Kenyatta University, Nairobi.

27. [27]. Pedrosa, F., Sergio, R. \& Pedro, J.C. (2007). University students' academic Performance. An integrative conceptual framework and empirical analysis.

28. [28]. Ugwulashi, C. S. (2011). Time Mangement and School Administration in Nigeria: Problems and Prospects. Journal of Educational and Social Research Vol. 1(2). PP 23-25.

29. [29]. Vitenu-Sackey, P. A., \& Bathuure, I. A. (2020). Does government expenditure on secondary education affect economic growth and secondary school enrollment? An empirical evidence of Ghana. International Journal of Business, Information and Management, 12 (3), 38-50.

30. [30]. Vitenu-Sackey, P. A. (2019). The Contributing Factors to Banks Performance in Ghana: Empirical Evidence from 1996 to 2017. International Journal of Management Sciences and Business Research 09, 63-78.

31. [31]. Vitenu-Sackey, P. A., \& Hongli, J. (2020). Financial inclusion and poverty alleviation: the role of commercial banks in West Africa. International Journal of Business, Economics and Management, 7 (1), 57-70. DOI: 10.18488/journal.62.2020.71.57.70

32. [32]. Vitenu-Sackey, P.A. (2021). The role of social media in financial development. Academia Letters, Article 3025, 1-7. https://doi.org/10.20935/AL3025

33. [33]. Vitenu-Sackey, P.A. (2020). The Impact of Social Media on Economic growth: Evidence from Facebook, Youtube, Twitter and Pinterest. International Journal of Business, Economics and Management, 7(4), 222-238. DOI: 10.18488/journal.62.2020.74.222.238

34. [34]. Vitenu-Sackey, P.A., Oppong, S., \& Bathuure, I.A. (2021). The impact of green fiscal policy on green technology investment: Evidence from China. International Journal of Management Excellence, 16(3), 2348-2358. 
35. [35]. Vitenu-Sackey, P. A., Barfi, R., \& Oppong, S. (2019). Stock Market Capitalization, Foreign Direct Investment and Stock Market Performance: A Comparative Study of Ghana and Nigeria, International Journal of Management Sciences and Business Research 09, 79-90.

36. [36]. Vitenu-Sackey, P.A, \& Alhassan, N. (2019). How does democracy affect poverty alleviation? Empirical evidence from Africa. International Journal of Management Sciences and Business Research, Dec-2019 ISSN (2226-8235) Vol-8, Issue 12, 21-31.

37. [37]. Wanyama, E. G. A., Simatwa, E. M. W., \& Okwach, T. O. (2018). Contribution of school administration to teaching-learning resources in enhancement of students' academic performance in secondary schools in Kenya: An empirical study across secondary schools in Emuhaya and Vihige Sub Counties. International Journal of Current Research Vol. 10, Issue, 03, pp.6730267314.

38. [38]. Wasan, S.Y.A, Lujain, A.A, Aisha, T.M.Z, Amal, M.S, Shagra, A.J, \& Zainab,A.A. (2017). The Effect of Time Management on Academic Performance among Students of Jazan University. The Egyptian Journal of Hospital Medicine Vol. 69 (8), Page 3042-3049. 